\begin{tabular}{c} 
International Journal of Engineering \& Technology, $7(4.33)(2018) 166-170$ \\
International Journal of Engineering \& Technology \\
WPC \\
Website: www.sciencepubco.com/index.php/IJET \\
Research paper \\
\hline
\end{tabular}

\title{
Character of Industrial 4.0 Skilled Workers
}

\author{
Ana $A^{1 *}$, Danny Meirawan ${ }^{2}$, Vina Dwiyanti ${ }^{3}$, Saripudin $S^{4}$ \\ ${ }^{1}$ Home Economics Education, Faculty of Technology and Vocational Education UPI, Indonesia \\ ${ }^{2}$ Civil Engineering Education, Faculty of Technology and Vocational Education UPI, Indonesia \\ ${ }^{3}$ Technology and Vocational Education Study Program, Post Graduate UPI, Indonesia \\ ${ }^{4}$ TEDC Polytechnic Bandung, Indonesia \\ *Corresponding author E-mail: ana@upi.edu
}

\begin{abstract}
Character of industrial 4.0 skilled worker is an important thing to prepare as soon to face industrial challenge in $4^{\text {th }}$ revolution industry. Industrial 4.0 is an industry that combines automation technology with cyber technology. It will give more impact and change everything totally. Various forms of education must be introduced, but it still does not solve problems for older workers and do not want to change following the development of industrial progress. Because in industrial 4.0 of disruption era will be ordered robot as an effective and efficiency solution for industry and less cost also. So, as worker we must improve our skill to compete and win it. In this research contains three main topics are (a) knowing the industrial Era 4.0, (b) disruption in the industrial Era 4.0 (c) Skills to face industry 4.0. This research method use literature review as 1) searching and selection 2) describe, 3) analysis. The conclusions overall suggest that all workers must improve their skills to face industrial 4.0 era. In this research suggest 4 main skills are effective communication, learn and innovative, information-media-technology, skills full in life and career.
\end{abstract}

Keywords: Industrial 4.0; worker skills; disruption era.

\section{Introduction}

Changes in the industrial world are always fast. Various changes that arise are able to shift even ruffle the old order to create a new one. Such conditions require industry players to follow the developments unless they want to be eroded or usually called as disruption. Disruption occurs when a party is present offering a more practical service with a lower price and thus many people turn to this new service. Shortly, disruption is an innovation [12]. Since several years ago Indonesia has experienced a disruption that shift the movement of industrial world so that job competition was no longer linear. The presence of application-based transportation service providers such as taxi online, has caused significant changes in people's lives. The income of local public transportation drivers dropped dramatically, taxi drivers raise strike due to loss of passengers, and large taxi companies like Blue Bird experienced a fantastic decline in profits. However, people consider that the presence of taxi online has made it easier for them.

The industrial world must improve and increase its capacity to compete. This disruption phenomenon not only touches the field of technology, but also changes many fields including human beings as workers [1]. In addition, increasing the capacity of workers as an important component in the industrial world. In the 1970 s, the third industrial revolution touched many fields of electronics and information technology, so that it always increases to a high level in the manufacturing industry [2]. Industrial developments have continued to occur. Now, there is a fourth industrial revolution or better known as industry 4.0. Research conducted by the Center for Indonesian Policy Studies (CIPS) states that change in industry 4.0 basically introduces the era of smart factories or smart factories with robots or Cyber Physical Systems (CPS) which will supervise the physical process inside the factory. This system has the ability to make its own decisions, so that it is feared that employment opportunities will be reduced and some aspects will be controlled by machines and robots.

The capacity of workers must be able to adapt with the shifts in the industrial era 4.0 or in the phenomenon of disruption, for example with many demands that must be met by workers. This is because this system will promote cyber and cheaper robots that cost compared to workers as sought and needed by the industry. So, this research will try to characterize workers with industrial skills 4.0 .

\section{Methodology}

This research method used was a literature review is limited to the characterize worker with industrial skills 4.0. The search of empirical articles was conducted in two phases. First phase, it searched for the empirical based article in electronic data bases using the keyword industrial skills 4.0 and open ended search period. In the second phase further searches on the papers cited in some of the article were carried out. The current review which started that the aims of a review summarize and highlight issues that research has yet resolve. Theories, idea are contained in literature source used as a basis for researcher searching, selection, describe, analyzes and bring new ideas to answer the problem of this research about characterize worker with industrial skills 4.0. This process was repeated until all articles were read and examined. It is possible that one article may yield more than another in the same topics. 


\section{Results and Discussion}

The identified research topics spread the category into three main categories: (a) knowing the industrial Era 4.0, (b) disruption in the industrial Era 4.0 (c) Skills to face industry 4.0.

\subsection{Knowing the Industrial Era 4.0}

Industry 4.0 is an industry that combines automation technology with cyber technology. This is a trend of automation and data exchange in manufacturing technology which include cyberphysical systems, Internet of Things (IoT), cloud computing and cognitive computing. Although it is still too early to speculate on labor conditions in the 4.0 Industry era globally, preparing workers to acquire different and new skills is a preventive effort. This can help raise employment rates. Sectors whose work is doing routine things may face challenges in keeping up with industry developments. Various forms of education must be introduced but it still does not solve problems for older workers and do not want to change following the development of industrial progress. This is a problem that may take longer to solve. Thus, Industry 4.0 can be seen from two points of view, namely macro and micro points of view.

\subsubsection{Viewpoint of Macro Industry 4.0}

The macro perspective on industry 4.0 is shown in Figure 1. This visualization shows the strength between product-life-rotation and the point of view of the placement of various elements and creative values in industry 4.0.

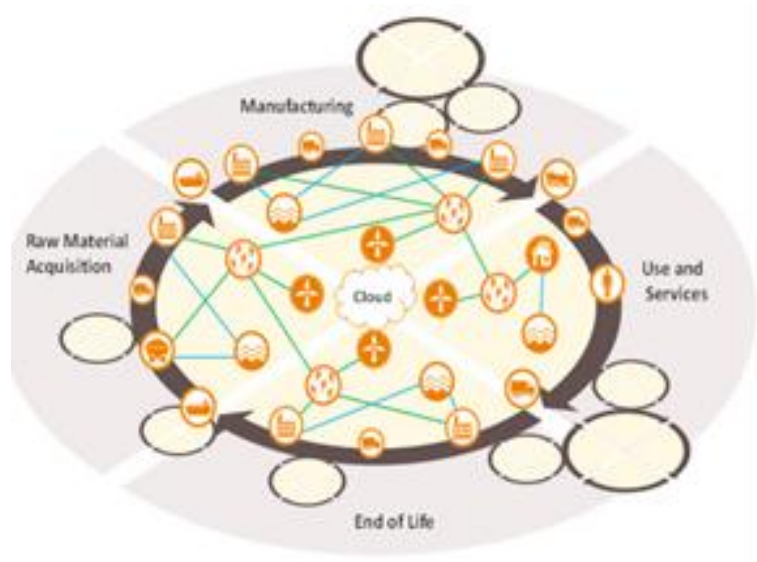

Fig. 1: Viewpoint of Macro Industry 4.0

Horizontal lines at the macro industry point of view 4.0 have high value through a network of different creative values with other creative factors such as tools, people, organizations, processes and products [2-3]. At this macro point of view, the completion of the process in production activities in the industry is very concerned about the environment as a new innovation and an innovative business model to lead in the industrial world.

The crossing lines in various stakeholders, products and equipment in this production circle are very close to the phase that continues to grow in the industrial environment. Products will be very different from stakeholders such as customers, workers or suppliers and equipment and factory equipment on a virtual network Circles in environmental activities will be very consistent and continue to grow so the production process in the industry or factory must be able to develop in terms of service, systems, recycling, and recovery [4-5]. The environment has a large contribution in the macro industry viewpoint 4.0. In addition to environmental contributions, the great opportunity in industry 4.0 to realize the values of industrial creation must optimize all the dimensions of opportunity such as economic, social and environmental. These opportunities are listed in Table 1.
Table 1: Opportunities to Maintain Resources in the Macro Viewpoint [2]

\begin{tabular}{|c|c|}
\hline 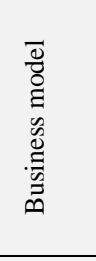 & $\begin{array}{l}\text { In the industrial era } 4.0 \text {, this business model possesses high de- } \\
\text { mand with the use of smart data in new service offerings [16]. } \\
\text { This development has positive and negative values such as the } \\
\text { impacts on the environment, but on the other hand can even con- } \\
\text { tribute well in overcoming social and environmental problems } \\
\text { [17]. This business concept is very important in functional sales } \\
\text { and accessibility of the products and will be important in the } \\
\text { process of buying and selling products. }\end{array}$ \\
\hline 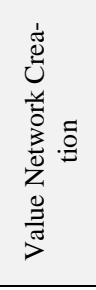 & $\begin{array}{l}\text { Cross linking of the value network creation in the } 4.0 \text { industrial } \\
\text { era offers new opportunities to realize the circle of life in symbi- } \\
\text { otic production. It is very efficient to coordinate between prod- } \\
\text { ucts, materials, energy and water flow in maintaining the best } \\
\text { possible life between production activities in the factory or indus- } \\
\text { try by paying attention to processes and reuse in activities in the } \\
\text { industry or factory. In addition, the environment and industry } \\
\text { symbiosis can also be used to realize the usefulness between the } \\
\text { two by using smart data in the local area [18]. }\end{array}$ \\
\hline
\end{tabular}

\subsubsection{Micro Industry Viewpoint 4.0}

This micro perspective in the 4.0 industry era illustrates how the process that occurs in smart manufacturing or smart factories begins with various important parts in the engineering dimension. The micro perspective in the industrial 4.0 era is illustrated in Figure 2.

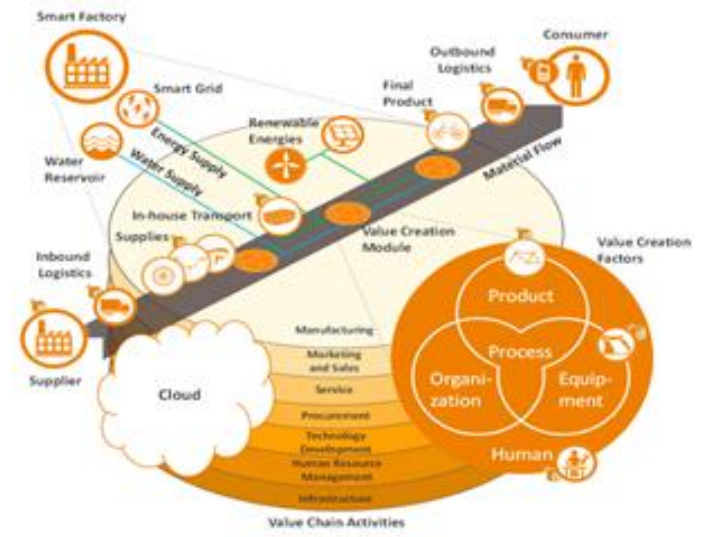

Fig. 2: Micro Industry Viewpoint 4.0

This smart factory system has links that can be realized using supporting applications. Therefore, it is called Cyber-Physical System (CPS) which operates in a self-organized and decentralized manner [6-8]. This is able to facilitate production activities and CPS has a large influence through virtual data changes and sustainability. Internet is one of the supporting systems in providing services [14]. This system is referred as part of the sociotechnical system. When this CPS is used, there will be an interaction between the machines with humans as workers who operates it [9] In addition, in the micro point of view of industry 4.0 there are opportunities as follows:

Table 2: Opportunities to Maintain Resources at the Micro Viewpoint

\begin{tabular}{|l|l|}
\hline & $\begin{array}{l}\text { Equipment in the industry or factory has a maximum storage } \\
\text { capacity of } 20 \text { years. The industry requires equipment or equip- } \\
\text { ment that is efficient with sensors and actuators as well as possible } \\
\text { for the use of controlled plants [19]. The approach used in this } \\
\text { case through the use of CPS in providing value creation and inno- } \\
\text { vation in the use and purchase and maintenance of equipment to } \\
\text { obtain low or low-cost expenditure. }\end{array}$ \\
\hline & $\begin{array}{l}\text { Humans as workers in the } 4.0 \text { industrial era are still needed who } \\
\text { has value of creation and innovation. The difference in approaches } \\
\text { for human factors in the opportunity to maintain resources needs } \\
\text { to be used social challenges in the industrial era 4.0 [13]. Im- } \\
\text { proved effective training for workers combined with Information } \\
\text { and Communication Technology (ICT), [20] increased motivation } \\
\text { in creating through CPS used in designing jobs [21] and the use of } \\
\text { ICTs in making these decisions needs to be implemented for each } \\
\text { in } \\
\text { individual. This is as a system for workers that is taken in the form } \\
\text { of an account on smart data as a product of individual worker } \\
\text { providers. }\end{array}$ \\
\hline \multirow{3}{*}{} &
\end{tabular}




\begin{tabular}{|c|c|}
\hline 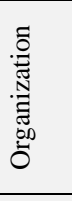 & $\begin{array}{l}\text { In this organizational factor, smart factory focuses on the efficient } \\
\text { allocation of products, materials, energy and water which are } \\
\text { taken through CPS with logistic smart, smart gird and efficient } \\
\text { distribution for consumers. This concept continues as an efficient } \\
\text { resource and is explained as one of the benefits for an essential } 4.0 \\
\text { industry [20]. }\end{array}$ \\
\hline D. & $\begin{array}{l}\text { The design of this process is carried out for resources holistically } \\
\text { and efficiently through the use of new technologies to facilitate } \\
\text { the production process in the industry or factory. }\end{array}$ \\
\hline & $\begin{array}{l}\text { The approach used on product factors focuses on providing ser- } \\
\text { vices in the form of good products for consumers. This concept } \\
\text { can be supported by an identification system application to recov- } \\
\text { er the produced products as well as the application of new addi- } \\
\text { tional services to products with a higher level and good for con- } \\
\text { sumers. }\end{array}$ \\
\hline
\end{tabular}

Simplifies the challenges of industry 4.0 namely (1) industrial readiness; (2) reliant workforce; (3) ease of socio-cultural arrangements; and (4) diversification and job creation and industry 4.0 opportunities namely (1) ecosystem innovation; (2) competitive industrial base; (3) investment in technology; and (4) integration of Small and Medium Enterprises (SMEs) and entrepreneurship.

\subsubsection{Disruption in the Industrial Era 4.0}

Currently, information flows so fast and consumer behavior changes. Therefore, companies are required to be able to adapt and respond to changes quickly as well. Digital transformation then becomes a solution to answer this challenge. Disruption is basically a transformation or a change that occurs due to the presence of the future to the present. Such changes make everything that usually walked normally suddenly have to change and stop due to the presence of something new. This can include new technology, new business processes, new players, new applications, new business models, or a combination of these factors [12]. The first industrial revolution era began when there was the invention of a steam engine. The era of second industrial revolution began when electricity was discovered and the third industrial revolution era began when the industry turned to robotic. In recent years, the fourth industrial revolution era has also taken a place. All of these revolutions have led to digitalization. Many think that doing digital transformation means going digital by creating a company website, social media account, or mobile application. This is not completely wrong but digital transformation is not just a matter of technology implementation or digitalization. Digital transformation has a wider scope which includes changes in business models and strategies, customer engagement, to corporate culture. Digital transformation is one of the things that happened in the industrial era 4.0, where the CPS system makes everything smart in facilitating and improving various aspect in the industry.

Many disruption phenomena occur in this century. Various large companies that dominated certain industries suddenly went bankrupt and some even had to break because of the presence of new innovating players. Disruption can certainly occur in various lines and industries, including in education, politics, and even government. Disruption can affect anyone at anytime.

\subsubsection{Skills to face industry 4.0}

Humans as workers must have the capabilities needed by industry as capital to enter the industrial market. Workers who are too old, possessing abilities that are not improved and minimal skills will be compared in the industrial era 4.0 [10]. In this industry era 4.0, workers are required to be able to follow the development of CPSbased technology. Otherwise, it is likely that the worker will be left behind even replaced by technological advances that provide many benefits with high low costs for the industry.

This 4.0 industry makes smart factory, which has a sophisticated information and communication system oriented towards advanced technology in the future [11]. One category that play a role in quality control is the control of existing human or worker factors in productive dimensions, maintenance, process control and employee involvement. An illustration of the impact of industry 4.0 on the controls and human factors is illustrated in Figure 3 .

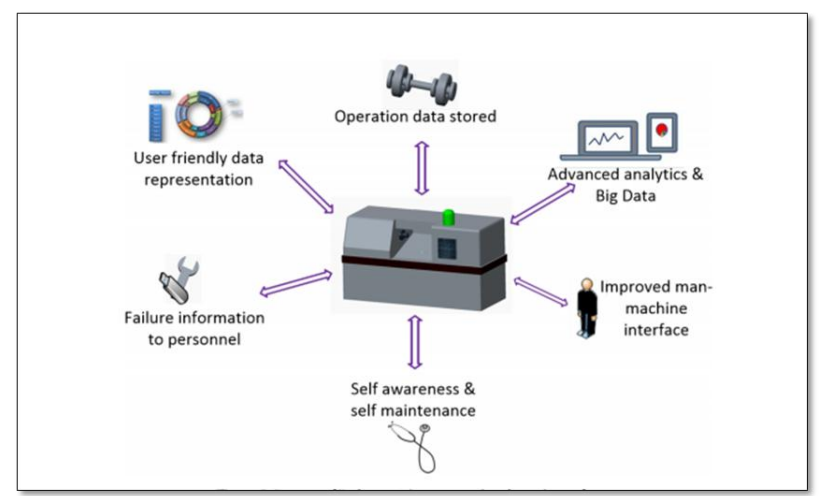

Fig. 3: Industry Influence 4.0 on Human or Worker Control Factors [11]

Figure 3 illustrates that the implementation of human factors as workers in the 4.0 industrial era must have the ability to control or use smart equipment well, have good performance to support the system applied to workers. One of the things that need to be considered is the ability to adapt workers to the disruption phenomenon in the industrial era 4.0, illustrated in Figure 4.

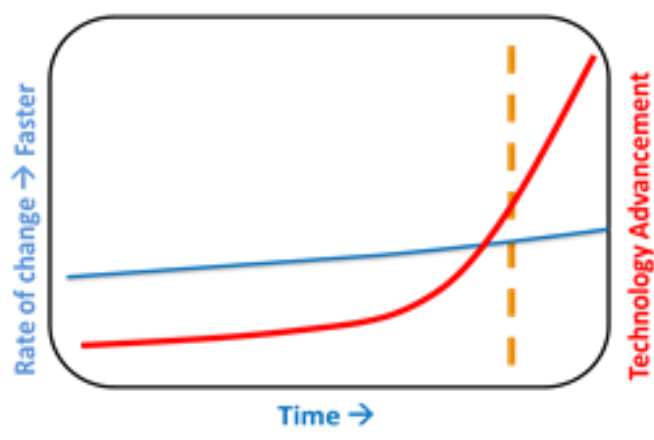

Fig. 4: "X"Factor Ability of Employee Adaptation

Figure 4 illustrates the speed of adapting to technological sophistication. Both of these factors are not directly proportional. The speed of workers' adaptation is lower than that of technological advances that continue to rise. This is a concern if workers do not want to lose their jobs. Humans as workers in the 4.0 industrial era must continue to grow and follow the development of the industry in order to survive in the industry. Some of the concerns in the implementation of tasks in the industrial era 4.0 as follows:

1) Knowledge of information and production technology

2) Knowledge of software structures

3) Understand the function of Hybrid Exercise

4) Experience in mechatronic

5) Sharpening skills in the social field of fellow workers

6) Sharpening the ability to use software

7) Able to change programs if required

8) Able to execute tasks measurably

9) Able to make decisions

10) Expert in their field for at least 2 years

11) Able to use the internet both manually and using data

12) Broad and directed knowledge

13) Expert in the process and use of technology

14) Have an optimistic spirit

15) Able to read and assess the use of data on the device or the machine used.

From the description of the tasks carried out in the industrial era above, it can be concluded that workers must develop their skills to meet the needs of industry in the industrial era 4.0. The capabil- 
ities that must be acquired and developed are illustrated in Figure 5.

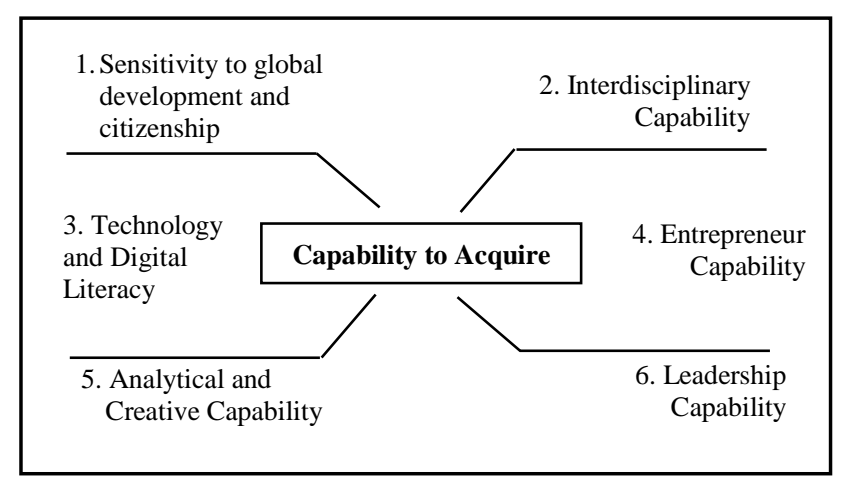

Fig. 5: The capabilities that must be acquired and developed

Besides abilities mentioned in Figure 5, data literacy is needed by each individual worker to improve skills in processing and analyzing big data for the benefit of improving public and business services. Technology literacy shows the ability to utilize digital technology to process data and information. Meanwhile, human literacy must be mastered because it shows elements of soft skill or individual character development to be able to collaborate, adaptive and wise in this industry 4.0 era as follows [15]:

1) Learning to think from the use of software

2) Able to understand network structures

3) Learn how to master big data technology

4) Learn how to work with various data formulas

5) Understand and master the process or implementation of work activities

6) Learn to take more responsibility in every job

7) Learn how to be communicative and cooperative workers

8) Learn how to have high innovation and initiation

9) Focus on developing sensitivity to the environment and social life through technological developments and innovations.

In the initial conclusions about the skills that must be possessed by workers in dealing with disruption in the 4.0 industrial era there are 4 main skills needed [15]. This needs to be endeavored by each individual worker to become a growing part of the development of the 4.0 industrial revolution, especially the disruption which following it. This four main expertise are illustrated in Figure 6 .

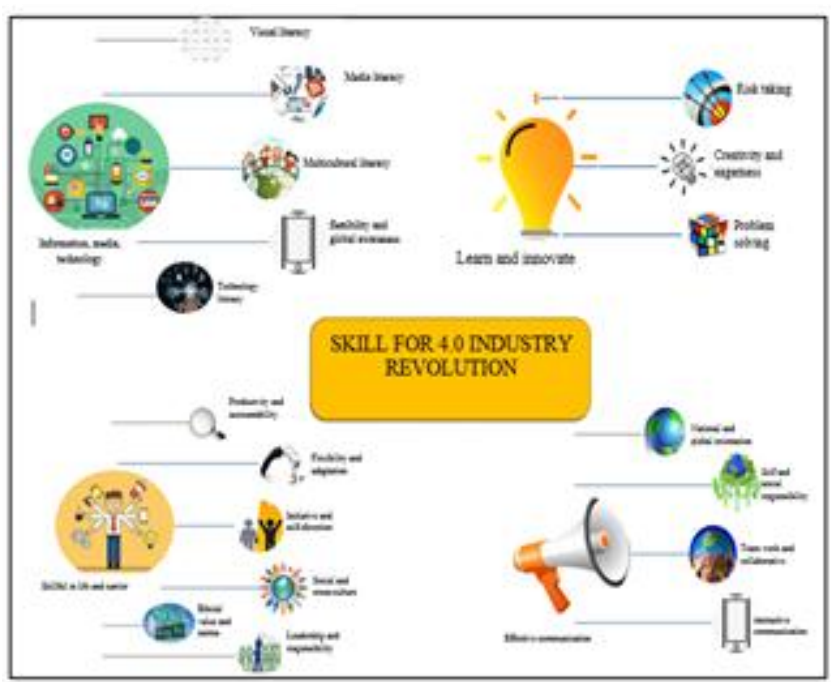

Fig. 6: Skill for 4.0 Industry Revolution

Figure 6 illustrates the 4 main skills that must be possessed in the face of the industrial revolution 4.0. First, to have information, media and technology skills, in other terms, must be technology literate which means information, media and technology skills including media literacy, visual literacy, multicultural literacy, global awareness, and technology literacy.

Second, to have learning and innovation skills that include creativity and curiosity, problem solving, and risk takers. Third, to be skilled in life and learning such as having a leadership and responsible spirit, having ethical and moral values, productivity and accountability, flexibility and adaptation, social and cross-cultural, initiative and self-direction.

Fourth, to have effective communication skills such as being able to work in teams and collaborating, to have personal and social responsibilities, to communicate interactively, and to have a national and global orientation

\section{Conclusion}

Skills for $4^{\text {th }}$ industry revolution or industrial 4.0 era is a phenomenon that will changed everything totally. This is a trend of automation and data exchange in manufacturing technology which include cyber-physical systems, Internet of Things (IoT), cloud computing and cognitive computing. Although it is still too early to speculate on labor conditions in the 4.0 Industry era globally, preparing workers to acquire different and new skills is a preventive effort. This can help raise employment rates. Sectors whose work is doing routine things may face challenges in keeping up with industry developments. Also, all workers must improve their skills to avoid changing by robot that industry needed cause it less cost, effective and efficient. In this revolution workers must have capability industry needed. Not only hard skills but also soft skills need. 4 main skills that must be possessed in the face of the industrial revolution 4.0. First to have information, media and technology skills, in other terms, must be technology literate which means information, media and technology skills including media literacy, visual literacy, multicultural literacy, global awareness, and technology literacy.

And then to have learning and innovation skills that include creativity and curiosity, problem solving, and risk takers. Next, to be skilled in life and learning such as having a leadership and responsible spirit, having ethical and moral values, productivity and accountability, flexibility and adaptation, social and cross-cultural, initiative and self-direction. And the last to have effective communication skills such as being able to work in teams and collaborating, to have personal and social responsibilities, to communicate interactively, and to have a national and global orientation. Hopefully, it will help all workers to improve their skills to have worker skills industrial 4.0 era.

\section{References}

[1] Bauer, W., Hämmerle, M., Schlund, S., \& Vocke, C. (2015). Transforming to a hyper-connected society and economy-towards an "Industry 4.0". Procedia Manufacturing, 3, 417-424.

[2] Stock, T., \& Seliger, G. (2016). Opportunities of sustainable manufacturing in industry 4.0. Procedia CIRP, 40, 536-541.

[3] Erol, S., Jäger, A., Hold, P., Ott, K., \& Sihn, W. (2016). Tangible Industry 4.0: A scenario-based approach to learning for the future of production. Procedia CIRP, 54, 13-18.

[4] Meisenheimer, J. R. (1998). The services industry in the good versus bad jobs debate. Monthly Lab. Rev., 121, 22.

[5] Stevens, A. H. (1997). Persistent effects of job displacement: The importance of multiple job losses. Journal of Labor Economics, 15(1, Part 1), 165-188.

[6] Schuh, G., Gartzen, T., Rodenhauser, T., \& Marks, A. (2015). Promoting work-based learning through industry 4.0. Procedia CIRP, 32, 82-87.

[7] Lane, K. L., Pierson, M. R., \& Givner, C. C. (2004). Secondary teachers' views on social competence: Skills essential for success. Journal of Special Education, 38(3), 174-186.

[8] Dewey, J. (1977). On industrial education. Curriculum Inquiry, 7(1), 53-60.

[9] Velde, C. (2009). Employers' perceptions of graduate competencies and future trends in higher vocational education in China. Journal of Vocational Education and Training, 61(1), 35-51. 
[10] Friedberg, L. (2003). The impact of technological change on older workers: Evidence from data on computer use. ILR Review, 56(3), 511-529.

[11] Sanders, A., Elangeswaran, C., \& Wulfsberg, J. (2016). Industry 4.0 implies lean manufacturing: Research activities in industry 4.0 function as enablers for lean manufacturing. Journal of Industrial Engineering and Management, 9(3), 811-833

[12] Rhenald, K. (2017). Self Disruption. Mizan.

[13] Acatech. (2013). Umsetzungsempfhlungen fur das Zukunftsprojekt Industrie 4.0-Abschlussbericht des Arbeitskreises Industrie 4.0. Acatech.

[14] Acatech. (2015). Umsetzungsstrategic Industrie 4.0 Ergebnisbreicht der Platform Industrie 4.0. Acatech.

[15] Paryono. (2018). Directions of TVET in Facing IR 4.0. In 2nd ATEF.

[16] Bocken, N. M., Short, S. W., Rana, P., \& Evans, S. (2014). A literature and practice review to develop sustainable business model archetypes. Journal of Cleaner Production, 65, 42-56.

[17] Schaltegger, S., \& Wagner, M. (2011). Sustainable entrepreneurship and sustainability innovation: Categories and interactions. Business Strategy and the Environment, 20(4), 222-237.

[18] Chertow, M. R. (2007). "Uncovering” industrial symbiosis. Journal of Industrial Ecology, 11(1), 11-30.

[19] Spath, D., Ganschar, O., Gerlach, S., Hämmerle, M., Krause, T., \& Schlund, S. (2013). Produktionsarbeit der Zukunft-Industrie 4.0, Fraunhofer-Institut für Arbeitswirtschaft und Organisation IAO.

[20] Kagermann, H., Lukas, W., \& Wahlster, W. (2015). Abschotten ist keine Alternative. VDI nachrichten, 16 